\title{
A New Isoflavone and Other Constituents from Roots of Clitoria guianensis
}

\author{
Camila L. Cunha, ${ }^{a}$ Susana C. Siebeneichler, ${ }^{b}$ Isabele R. Nascimento ${ }^{\circledR a}{ }^{a}$ and \\ Juliana C. Holzbach ${ }^{\circledR} *, b$ \\ ${ }^{a}$ Instituto de Química, Universidade Estadual Paulista (Unesp), 14800-060 Araraquara-SP, Brazil \\ ${ }^{b}$ Universidade Federal do Tocantins (UFT), CP 66, 77402-970 Gurupi-TO, Brazil
}

\begin{abstract}
A new isoflavone named pratensein-7-O- $\beta$-D-rutinoside [(-)-7- $O-\alpha$-L-rhamnopyranosyl$(1 \rightarrow 6)$ - $\beta$-D-glucopyranosyl-5,3'-dihydroxy-4'-methoxyisoflavone] and the known compounds biochanin A-7-O- $\beta$-D-rutinoside, 6-deoxyclitoriacetal 11-O- $\beta$-D-glucopyranoside, 6-deoxyclitoriacetal, $(2 S)$-naringenin-6-C- $\beta$-D-glucopyranoside, $(2 R)$-naringenin6-C- $\beta$-D-glucopyranoside, tachioside, and koaburaside were isolated from the roots of Clitoria guianensis (Aubl.) Benth var. guianensis (Fabaceae), a subshrub found in the Brazilian Cerrado biome. The structures of the compounds were identified by physical and spectroscopic data measurements (specific rotation $\left([\alpha]_{\mathrm{D}}\right)$, circular dichroism (CD), ultraviolet (UV), infrared (IR), 1D and 2D nuclear magnetic resonance (NMR), and mass spectrometry (MS)). The EtOAc fraction of the roots exhibited high toxicity against Artemia salina with median lethal dose $\left(\mathrm{LD}_{50}\right)$ value of $8.53 \mathrm{mg} \mathrm{L}^{-1}$.
\end{abstract}

Keywords: Clitoria guianensis, Fabaceae, isoflavone, flavanone

\section{Introduction}

Clitoria Linn. is a genus of the Fabaceae family with about sixty species widely distributed throughout the tropical regions of Africa, Asia and Central America. ${ }^{1,2}$ In Brazil there are 28 Clitoria species found mainly in the northern region. Clitoria guianensis, also known as "Vergateza", is a subshrub with purple flowers present on dry ground. ${ }^{3,4}$

Several plants of Clitoria genus are traditionally used for the treatment of respiratory, neurological, urinary, and skin disorders. ${ }^{5,6}$ Ethnobotanical studies in Brazil reported that Clitoria guianensis is used in folk medicine in the form of decoction or "garrafadas" (medicinal plants mixed with alcoholic beverages) for mental disorders and sexual stimulant. ${ }^{7,8}$ In this genus, Clitoria ternatea is the species with the highest number of pharmacological activities reported, such as antimicrobial, antipyretic, anti-inflammatory, anticonvulsant, diuretic, anesthetic, antidiabetic, and insecticidal. ${ }^{2,9}$

Isoflavonoids and rotenoids are naturally found in plants of the Fabaceae (Leguminosae) family. ${ }^{10,11}$ Isoflavonoids have shown potential as anticancer, antimutagenic, antioxidant, and antimicrobial. ${ }^{12-14}$ Rotenoids exhibit anti-

*e-mail: juholzbach@uft.edu.br inflammatory, antiviral, anticancer activities and are used as pesticides, being classified as biological pesticides, due to their natural origin. ${ }^{15,16}$

The chemical constituents isolated from the Clitoria genus, mostly from C. ternatea and C. fairchildiana, are rotenoids, ${ }^{17-22}$ flavonols, anthocyanins, ${ }^{6,23,24}$ alkaloids, ${ }^{25}$ triterpenoids, ${ }^{26}$ and others. There are no reports of isoflavone isolation from Clitoria.

In this paper, we report the first phytochemical study of Clitoria guianensis (Aubl.) Benth var. guianensis, the isolation and the structural elucidation of pratensein$7-O$ - $\beta$-D-rutinoside as a new isoflavone, and seven known compounds including rotenoids, isoflavone, flavanones and phenolic glycosides. The EtOH crude extract, and $n$-hexane (Hex) and ethyl acetate (EtOAc) fractions of $C$. guianensis roots were evaluated for toxicity against Artemia salina.

\section{Results and Discussion}

Clitoria guianensis was collected from Brazilian Cerrado biome and the roots were extracted with ethanol and further partitioned with Hex and EtOAc. The toxicity testing using brine shrimp (Artemia salina) of EtOH crude extract, Hex, and EtOAc fractions showed median lethal dose $\left(\mathrm{LD}_{50}\right)$ values of $23.44,41.16$, and $8.53 \mathrm{mg} \mathrm{L}^{-1}$, respectively. The samples are considered highly toxic 
$\left(\mathrm{LD}_{50}<100 \mathrm{mg} \mathrm{L}^{-1}\right)^{27}$ and the fractions presented lower $\mathrm{LD}_{50}$ values than $C$. ternatea leaves extracts tested, ${ }^{28}$ suggesting the presence of compounds with potential pharmacological activity.

The EtOAc fraction was fractionated and resulted in the new (-)-7- $O$ - $\alpha$-L-rhamnopyranosyl$(1 \rightarrow 6)$ - $\beta$-D-glucopyranosy $1-5,3^{\prime}$ - dihydroxy4'-methoxyisoflavone (pratensein-7-O- $\beta$-D-rutinoside, 1) and seven known compounds: biochanin A-7-O- $\beta$-D-rutinoside (2), ${ }^{29}$ 6-deoxyclitoriacetal 11-O- $\beta$-D-glucopyranoside (3), ${ }^{18}$ 6-deoxyclitoriacetal (4), ${ }^{30}(2 S)$-naringenin-6-C- $\beta$-D-glucopyranoside (5), $(2 R)$-naringenin-6-C- $\beta$-D-glucopyranoside $(6),{ }^{31}$ 4-hydroxy-3-methoxyphenyl-1-O- $\beta$-D-glucopyranoside (tachioside, 7), ${ }^{32}$ and 4-hydroxy-3,5-dimethoxyphenyl1-O- $\beta$-D-glucopyranoside (koaburaside, 8$)^{33}$ (Figure 1).

Compound $\mathbf{1}$ was isolated as an optically active (specific rotation $\left.\left([\alpha]_{\mathrm{D}}\right)-63.0, c 0.1, \mathrm{CH}_{3} \mathrm{OH}\right)$, brownish amorphous powder. Electrospray ionization quarupole time-of-flight high-resolution mass spectrometry (ESI-QTOF)-HRMS analysis exhibited an ion at $m / z 609.1822[\mathrm{M}+\mathrm{H}]^{+}$ indicating the molecular formula $\mathrm{C}_{28} \mathrm{H}_{32} \mathrm{O}_{15}$ (calcd. for $\left.\mathrm{C}_{28} \mathrm{H}_{33} \mathrm{O}_{15}, 609.1814\right)$. The second order fragmentation (MS/MS) of the protonated molecule at $\mathrm{m} / \mathrm{z} 609.1815$ showed base peak at $m / z 463.1232$, which corresponds to loss of one methyl-pentose (146 Da), and another signal observed at $\mathrm{m} / \mathrm{z} 301.0701$ which refers to the loss of one hexose (162 Da), successively. The infrared (IR) spectrum showed characteristic absorption bands of $\alpha, \beta$-unsaturated ketone at $1655 \mathrm{~cm}^{-1}$ and hydroxyl groups at 3396 and $1052 \mathrm{~cm}^{-1}$. The distortionless enhancement by polarization transfer with retention of quaternaries nuclear magnetic resonance (DEPTQ NMR) spectrum showed 28 carbon signals including the presence of an $\alpha, \beta$-unsaturated ketone group at $\delta_{\mathrm{C}} 180.5(\mathrm{C}-4)$ and 155.1 (C-2) (Table 1). The ${ }^{1} \mathrm{H}$ NMR spectrum exhibited a characteristic singlet at $\delta_{\mathrm{H}} 8.40$ assigned to $\mathrm{H}-2$ of an isoflavone, and confirmed by the correlation from this hydrogen signal with $\mathrm{C}-2$ $\left(\delta_{\mathrm{C}} 155.1\right)$ in the heteronuclear single quantum correlation (HSQC) spectrum. Furthermore, ${ }^{1} \mathrm{H}$ NMR spectrum showed two typical proton doublets of a 5,7-substituted isoflavone A-ring $\left(\delta_{\mathrm{H}} 6.44, \mathrm{~d}, J 2.1 \mathrm{~Hz}, \mathrm{H}-6\right.$ and $\delta_{\mathrm{H}} 6.73, \mathrm{~d}, J 2.1 \mathrm{~Hz}$, H-8) and three signals referring to 1,3,4-trisubstituted system on B-ring $\left(\delta_{\mathrm{H}} 7.05, \mathrm{~d}, J 1.5 \mathrm{~Hz}, \mathrm{H}-2^{2} ; \delta_{\mathrm{H}} 6.98, \mathrm{~d}, J 8.4 \mathrm{~Hz}\right.$, H-5'; and $\delta_{\mathrm{H}} 6.96$, dd, $\left.J 8.4,1.5 \mathrm{~Hz}, \mathrm{H}-6^{\prime}\right)$, concluding that compound $\mathbf{1}$ is a $5,7,3^{\prime}, 4^{\prime}$-'tetrasubstituted isoflavone.

Two anomeric signals of the sugar units at $\delta_{\mathrm{H}} 5.02$ (d, $J 7.3 \mathrm{~Hz}, \mathrm{H}-1$ ") and $\delta_{\mathrm{H}} 4.52$ (br s, H-1"') were also observed. The magnitude of the coupling constants suggests the $\beta$ - and $\alpha$-configuration, respectively. The 1D-TOCSY (total correlation spectroscopy) spectra obtained by irradiating on $\delta_{\mathrm{H}} 5.02$ and 4.52 , together with HSQC and mass fragmentation data, confirmed the glucose and rhamnose units, respectively. The downfield

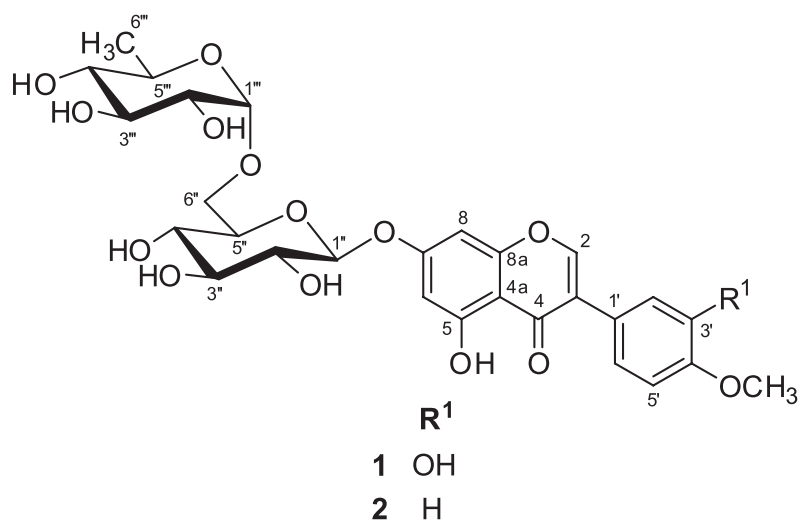

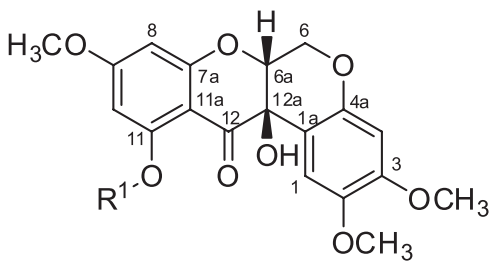

$3 \beta$-Glc

$4 \mathrm{H}$<smiles>[R]c1cc(O[C@@H]2O[C@H]3[C@@H](O)[C@@H](O)[C@@H](O)[C@H]3O2)cc(OC)c1O</smiles>

$\mathbf{R}^{1}$

$7 \mathrm{H}$

$8 \mathrm{OCH}_{3}$

Figure 1. Chemical constituents from roots of C. guianensis. 
Table 1. NMR data for compound 1 (600 and $151 \mathrm{MHz}$, DMSO- $d_{6}$ )

\begin{tabular}{|c|c|c|c|}
\hline Position & $\delta_{\mathrm{C}} / \mathrm{ppm}$ & $\delta_{\mathrm{H}}(J / \mathrm{Hz}) / \mathrm{ppm}$ & HMBC \\
\hline 2 & 155.1 & $8.40(\mathrm{~s})$ & \\
\hline 3 & 122.3 & - & $\mathrm{H}-2$ \\
\hline 4 & 180.5 & - & $\mathrm{H}-2$ \\
\hline $4 a$ & 106.2 & - & H-6, H-8 \\
\hline 5 & 161.5 & - & \\
\hline 6 & 99.8 & $6.44(\mathrm{~d}, J 2.1)$ & $\mathrm{H}-8$ \\
\hline 7 & 162.9 & - & H-1", H-6, H-8 \\
\hline 8 & 94.7 & $6.73(\mathrm{~d}, J 2.1)$ & H-6 \\
\hline $8 a$ & 157.2 & - & H-2, H-8 \\
\hline 1 , & 123.2 & - & H-2, H-5, \\
\hline 2 , & 116.3 & $7.05(\mathrm{~d}, J 1.5)$ & H-6 \\
\hline 3 , & 146.2 & - & $\mathrm{H}-5$, \\
\hline 4 & 147.8 & - & H-2', H-6' \\
\hline 5 , & 112.0 & $6.98(\mathrm{~d}, J 8.4)$ & \\
\hline $6^{\prime}$ & 119.9 & $6.96(\mathrm{dd}, J 8.4 ; 1.5)$ & $\mathrm{H}-2$ \\
\hline $1 "$ & 100.0 & $5.02(\mathrm{~d}, J 7.3)$ & H-2", H-3" \\
\hline $2 "$ & 73.1 & $3.26-3.31(\mathrm{~m})$ & H-1", H-4" \\
\hline $3 "$ & 75.7 & 3.59 (br t, $J 9.0)$ & $\mathrm{H}-1 ", \mathrm{H}-5 "$ \\
\hline $4 "$ & 70.0 & $3.10-3.18(\mathrm{~m})$ & $\mathrm{H}-5 "$ \\
\hline $5 "$ & 76.5 & $3.26-3.31(\mathrm{~m})$ & H-3” \\
\hline $6 "$ & 66.4 & $\begin{array}{c}3.35-3.40(\mathrm{~m}) \\
3.88(\mathrm{br} \mathrm{d}, J 9.8)\end{array}$ & $\mathrm{H}-1$ '”, \\
\hline $1, "$ & 100.7 & 4.52 (br s) & $\mathrm{H}-5$, \\
\hline $2, "$ & 70.7 & $3.52-3.54(\mathrm{~m})$ & $\mathrm{H}-4 ”$ \\
\hline $3, "$ & 70.3 & $3.64(\mathrm{br} \mathrm{s})$ & $\mathrm{H}-4$ "” \\
\hline $4, "$ & 72.2 & $3.10-3.18(\mathrm{~m})$ & H-2"', H-3"', H-6"' \\
\hline $5, "$ & 68.4 & $3.42-3.45(\mathrm{~m})$ & $\mathrm{H}-6 ", \mathrm{H}-1 "$, \\
\hline $6 "$, & 17.9 & $1.10(\mathrm{~d}, J 6.2)$ & H-4"', H-5"” \\
\hline $\mathrm{CH}_{3} \mathrm{O}-4$, & 55.7 & $3.80(\mathrm{~s})$ & \\
\hline HO-5 & - & $12.88(\mathrm{~s})$ & \\
\hline
\end{tabular}

HMBC: heteronuclear multiple bond correlation.

shift of the C-6" suggested the position of attachment of rhamnose at C-6" of glucose. This was further confirmed by the interaction of $\mathrm{H}-6$ " $\left(\delta_{\mathrm{H}} 3.35-3.40\right.$ and 3.88) with the anomeric carbon $\delta_{\mathrm{C}} 100.7$ (C-1"') in the heteronuclear multiple bond correlation (HMBC) spectrum and indicated that the rhamnose unit is connected to glucose by C-6". Correlation of the anomeric proton $\delta_{\mathrm{H}} 5.02$ (H-1") with $\delta_{\mathrm{C}} 162.9$ indicated that the glucose unit is connected to C-7. The position of the methoxyl group at C-4' in $\mathbf{1}$ was corroborated by nuclear Overhauser effect spectroscopy (NOESY) experiments that showed the interaction between $\mathrm{C}_{3} \mathrm{O}$ and $\mathrm{H}-5$ '. The configurations of the glucose and rhamnose units of the rutinoside were suggested based on natural occurrence as the $\mathrm{D}$ and $\mathrm{L}$ isomers, respectively. ${ }^{34}$
A similar structure was reported by Park et al., ${ }^{35}$ containing an $\mathrm{OH}$ group at $\mathrm{C}-4$ '. This new isoflavone (-)-7-O- $\alpha$-L-rhamnopyranosyl- $(1 \rightarrow 6)-\beta$-D-glucopyranosyl-5,3'-dihydroxy-4'-methoxyisoflavone was named pratensein-7-O- $\beta$-D-rutinoside (1).

Compounds 5 and $\mathbf{6}$ showed different elution order in the achiral high-performance liquid chromatography (HPLC) system analysis but the same ultraviolet (UV), MS and NMR spectra. Flavanones glycosides may exist in the form of diastereoisomers due to the presence of a chiral center at the C-2 position. ${ }^{36}$ As compound 5 exhibited a negative Cotton effect at $290 \mathrm{~nm}$ while $\mathbf{6}$ displayed a positive Cotton effect, the structures $\mathbf{5}$ and $\mathbf{6}$ could be established as ( $2 S)$ - and as $(2 R)$-naringenin-6- $C$ - $\beta$-D-glucopyranoside, respectively. ${ }^{37,38}$

\section{Conclusions}

This is the first report of phytochemical study of Clitoria guianensis (Aubl.) Benth var. guianensis. The high toxicity of its extract and fractions against Artemia salina indicates the presence of potent bioactive compounds. The new compound pratensein-7-O- $\beta$-D-rutinoside and the known biochanin A-7-O- $\beta$-D-rutinoside are the first isoflavones reported in the Clitoria genus. The isolation of compounds 1-8 contributes to the phytochemistry of the Clitoria genus and expands knowledge about the chemodiversity of natural products from Brazilian Cerrado biome.

\section{Experimental}

\section{General experimental procedures}

One-dimensional $\left({ }^{1} \mathrm{H},{ }^{13} \mathrm{C}\right.$, and TOCSY $)$ and two-dimensional $\left({ }^{1} \mathrm{H}-{ }^{1} \mathrm{H}\right.$ correlation spectroscopy (COSY), HSQC, and HMBC) NMR experiments were performed on a Bruker Avance ${ }^{\mathrm{TM}}$ III 600 spectrometer $(14.1 \mathrm{~T})$ at $600 \mathrm{MHz}\left({ }^{1} \mathrm{H}\right)$ and $151 \mathrm{MHz}\left({ }^{13} \mathrm{C}\right)$ using deuterated solvents $\left(\mathrm{CDCl}_{3}, \mathrm{CD}_{3} \mathrm{OD}\right.$, and dimethyl sulfoxide (DMSO- $\left.\left.d_{6}\right)\right)(99.98 \%$ D) as internal standards for ${ }^{13} \mathrm{C}$ NMR chemical shifts and residual solvent as an internal standard for ${ }^{1} \mathrm{H}$ NMR. $\delta$ values are reported relative to $\mathrm{Me}_{4} \mathrm{Si}$. High-resolution mass spectra were obtained on a ESI-QTOF-MS Bruker ${ }^{\mathrm{TM}}$ Maxis Impact mass spectrometer. Fourier transform infrared (FTIR) spectra were obtained on a Bruker VERTEX 70 FTIR spectrometer using ATR (attenuated total reflectance). Optical rotations were measured on a PerkinElmer ${ }^{\mathrm{TM}} 341$-LC polarimeter. HPLC analyses were performed using a Jasco ${ }^{\mathrm{TM}}$ LC-NetII/ADC liquid chromatograph, equipped with photodiode array 
(MD-2018 Plus) and circular dichroism (CD) (2095 Plus) detectors. Zorbax RX C18 columns $(5 \mu \mathrm{m}, 9.4 \times 250 \mathrm{~mm}$ and $5 \mu \mathrm{m}, 4.6 \times 250 \mathrm{~mm}$, Agilent) were used for semipreparative and analytical analysis. Solvents employed were HPLC grade from Mallinckrodt (Paris, KY, USA). Ultrapure water was obtained from Direct- $\mathrm{Q}^{\mathrm{TM}} 3 \mathrm{UV}$ System from Millipore (Billerica, MA, USA).

\section{Plant material}

The plant was collected in Gurupi ( $\left.11^{\circ} 43^{\prime} \mathrm{S}, 49^{\circ} 15^{\prime} \mathrm{W}\right)$, Tocantins, Brazil, in November 2013, and identified by Prof Rodney Haulien Oliveira Viana as Clitoria guianensis (Aubl.) Benth var. guianensis. A voucher specimen (10.637) was deposited at Herbário do Tocantins (HTO), Porto Nacional, TO, Brazil. The materials were separated according to the plant parts and dried (ca. $45^{\circ} \mathrm{C}$ ).

\section{Extraction and isolation}

The roots $(398.5 \mathrm{~g})$ were ground and exhaustively extracted three times at room temperature with ethanol $(3 \times$ ca. $300 \mathrm{~mL})$. The plant material remained in contact with the solvent for 7 days and was manually shaken every $12 \mathrm{~h}$ for $2 \mathrm{~min}$, for each extraction. The EtOH crude extract $(12.1 \mathrm{~g})$ was dissolved in a mixture of $\mathrm{MeOH}: \mathrm{H}_{2} \mathrm{O}(250 \mathrm{~mL}$, $1: 1 \mathrm{v} / \mathrm{v}$ ) and then subjected to liquid-liquid partition with Hex and EtOAc. The solvents were removed under reduced pressure, resulting in the remaining $\mathrm{H}_{2} \mathrm{O}(2.2 \mathrm{~g})$, EtOAc $(5.4 \mathrm{~g})$ and Hex $(3.3 \mathrm{~g})$ fractions.

The EtOAc fraction ( $1.42 \mathrm{~g}$ ) was subjected to column chromatography (CC) $(2.3 \times 29.0 \mathrm{~cm}$, silica gel eluted with a gradient of $1: 1 n$-hexane/ $\mathrm{CHCl}_{3} \rightarrow 100 \% \mathrm{MeOH}$ ) to give 25 subfractions (ca. $25 \mathrm{~mL}$ each; SFr1-SFr25). Subfractions SFr13 $\left(\mathrm{CHCl}_{3}: \mathrm{MeOH} 6: 4\right)$ and $\mathrm{SFr} 9\left(\mathrm{CHCl}_{3}: \mathrm{MeOH}\right.$ 7:3) gave 3 (141.8 $\mathrm{mg}$ ) and 4 (19.8 $\mathrm{mg})$, respectively. SFr16 + SFr17 (121.0 mg, $\left.\mathrm{CHCl}_{3}: \mathrm{MeOH} 6: 4\right)$ were submitted to $\mathrm{HPLC}\left(\mathrm{C} 18, \mathrm{MeOH} / \mathrm{H}_{2} \mathrm{O} 5 \rightarrow 30 \% \mathrm{MeOH}\right.$ in $5 \mathrm{~min}, 30 \rightarrow 80 \% \mathrm{MeOH}$ in $35 \mathrm{~min}$, flow rate $2.5 \mathrm{~mL} \mathrm{~min}^{-1}$, $\lambda=274 \mathrm{~nm}$ ) on semi-preparative scale, resulting in the isolation of: $\mathbf{1}(9.0 \mathrm{mg}), \mathbf{2}(10.8 \mathrm{mg}), \mathbf{5}(1.5 \mathrm{mg}), \mathbf{6}(1.8 \mathrm{mg})$, $\mathbf{7}(0.6 \mathrm{mg})$ and $\mathbf{8}(0.4 \mathrm{mg})$.

\section{Toxicity testing using Artemia salina}

The brine shrimp lethality assay was performed by the method of McLaughlin. ${ }^{39,40}$ Brine shrimp eggs (Artemia salina) were hatched in saline solution of $\mathrm{NaCl}$ $\left(38 \mathrm{~g} \mathrm{~L}^{-1}\right)$ and were incubated for $24 \mathrm{~h}$. The saltwater solution was aerated continuously during incubation with an aquarium air pump. The nauplii (10 units) were added to each set of tubes containing EtOH crude extract, Hex and EtOAc fractions (solubilized in saline solution containing $1 \%$ DMSO). The samples were tested in triplicate at concentrations of $2,5,7,10,20,35,50$, and $100 \mathrm{mg} \mathrm{L}^{-1}$. For each concentration, three test tubes containing the same volume of DMSO plus seawater and brine shrimp nauplii were used as control group. Survival was measured after $24 \mathrm{~h}$ incubation. The collected data were computerized and $\mathrm{LC}_{50}$ values determined by Probit analysis.

Pratensein-7-O- $\beta$-D-rutinoside [(-)-7-O- $\alpha$-L-rhamnopyranosyl-( $1 \rightarrow 6)$ - $\beta$-D-glucopyranosyl-5,3'-dihydroxy4'-methoxyisoflavone] (1)

Brownish amorphous powder; mp 151.8-153.5 ${ }^{\circ} \mathrm{C}$; $[\alpha]_{\mathrm{D}}{ }^{26}-63.0$ ( $\left.c 0.1, \mathrm{MeOH}\right)$; UV-Vis $(\mathrm{MeOH}) \lambda / \mathrm{nm} 260$; IR (attenuated total reflectance (ATR)) $v / \mathrm{cm}^{-1} 3396$, $2919,1655,1275,1052 ;{ }^{1} \mathrm{H}$ and ${ }^{13} \mathrm{C}$ NMR data see Table 1; HRMS [electrospray ionization quadrupole time-of-flight (ESI-(+)-QTOF)] $\mathrm{m} / \mathrm{z}$, calcd. for $\mathrm{C}_{28} \mathrm{H}_{33} \mathrm{O}_{15}[\mathrm{M}+\mathrm{H}]^{+}$: 609.1814, found: 609.1822 .

\section{Supplementary Information}

Supplementary information (1D and 2D NMR, MS and IR spectroscopic data of compound $\mathbf{1}$ and ${ }^{1} \mathrm{H}$ NMR data of 2-8) is available free of charge at http://jbcs.sbq. org.br as PDF file.

\section{Acknowledgments}

The authors thank the FINEP for financial supports and PIBIC/UFT for providing the fellowship to C. L. C.

\section{References}

1. Zingare, M. L.; Zingare, P. L.; Dubey, A. K.; Int. J. Pharm. Biol. Sci. 2013, 3, 203.

2. Singh, N. K.; Garabadu, D.; Sharma, P.; Shrivastava, S. K.; Mishra, P.; J. Ethnopharmacol. 2018, 224, 15.

3. Durigan, G.; Pilon, N. A. L.; Assis, G. B.; Souza, F. M.; Baitello, J. B.; Plantas Pequenas do Cerrado: Biodiversidade Negligenciada, $1^{\text {st }}$ ed.; SMA: São Paulo, 2018.

4. Fantz, P. R. In Contributions to Botany; Lipscomb, B. L., ed.; The Botanical Research Institute of Texas: Fort Worth, USA, 1994, p. 721.

5. Gollen, B.; Mehla, J.; Gupta, P.; J. Pharmacol. Rep. 2018, 3, 141.

6. Singh, K. N.; Gupta, J. K.; Shah, K.; Mishra, P.; Tripathi, A.; Chauhan, N.; Upmanyu, N. In Medicinal Plants and Its Therapeutic Uses; Kshetrimayum, B., ed.; OMICS Group eBooks: Foster City, USA, 2017, ch 7. 
7. de Souza, C. D.; Felfili, J. M.; Acta Bot. Bras. 2006, 20, 135.

8. Verde, G. M. V.; Paula, J. R.; Caneiro, D. M.; Rev. Bras. Farmacogn. 2003, suppl. 1, 64.

9. Zakaria, N. N. A.; Okello, E. J.; Howes, M.-J.; Birch-Machin, M. A.; Bowman, A.; Phytother. Res. 2018, 32, 1064.

10. El-Kassem, L. T. A.; Hawas, U. W.; Abdelfattah, M. S.; Mostafa, A. A.; Nat. Prod. Res. 2020, 34, 613.

11. Veitch, N. C.; Nat. Prod. Rep. 2007, 24, 417.

12. Sherif, S. H.; Gebreyohannes, B. T.; J. Chem. 2018, 2018, 2.

13. Miadoková, E.; Interdiscip. Toxicol. 2009, 2, 211.

14. Ko, K.; Asian Pac. J. Cancer Prev. 2014, 15, 7001.

15. Baldino, L.; Scognamiglio, M.; Reverchon, E.; J. Chem. Technol. Biotechnol. 2018, 93, 3656.

16. Gupta, R. C.; Milatovic, D. In Biomarkers in Toxicology; Gupta, R. C., ed.; Academic Press: Boston, 2014, p. 389.

17. Silva, B. P.; Bernardo, R. R.; Parente, J. P.; Phytochemistry 1998, 49, 1787.

18. da Silva, B. P.; Bernardo, R. R.; Parente, J. P.; Planta Med. 1998, 64, 285.

19. Santos, R. A. F.; David, J. M.; Ferreira, A. S.; David, J. P.; Fontana, R.; Rev. Fitos 2018, 12, 83.

20. Mathias, L.; Mors, W. B.; Parente, J.; Phytochemistry 1998, 48, 1449.

21. Silva, B. P. D. A.; Bernardo, R. R.; Parente, J. P.; Phytochemistry 1998, 47, 121.

22. Lin, L.-J.; Ruangrungsi, N.; Cordell, G. A.; Shieh, H.-L.; You, M.; Pezzuto, J. M.; Phytochemistry 1992, 31, 4329.

23. Kazuma, K.; Noda, N.; Suzuki, M.; Phytochemistry 2003, 64, 1133.

24. Srivastava, B. K.; Pande, C. S.; Planta Med. 1977, 32, 138.

25. Ilayaraja, S.; Manivannan, R.; Heterocycl. Lett. 2018, 8, 603.

26. Swain, S. S.; Rout, K. K.; Chand, P. K.; Appl. Biochem. Biotechnol. 2012, 168, 487.
27. Nguta, J.; Mbaria, J. M.; Gakuya, D.; Gathumbi, P. K.; Kabasa, J. D.; Kiama, S. G.; Open Conf. Proc. J. 2012, 3, 30.

28. Rahman, A. S.; Arslan, I.; Saha, R.; Talukder, N.; Khaleque, S.; Au, H. A.; Bangladesh J. Physiol. Pharmacol. 2006, 22, 18.

29. da Silva, V. C.; de Carvalho, M. G.; Silva, S. L. C.; Rev. Latinoam. Quim. 2007, 35, 13.

30. Khorphueng, P.; Tummatorn, J.; Petsom, A.; Taylor, R. J. K.; Roengsumran, S.; Tetrahedron Lett. 2006, 47, 5989.

31. Budzianowski, J.; Skrzypczakowa, L.; Phytochemistry 1978, 17, 2044.

32. Shrestha, S.; Lee, D.-Y.; Park, J.-H.; Cho, J.-G.; Lee, D.-S.; Li, B.; Kim, Y.-C.; Kim, G.-S.; Bang, M.-H.; Baek, N.-I.; Nat. Prod. Res. 2013, 27, 2244.

33. Shao, J.-H.; Chen, J.; Zhao, C.-C.; Shen, J.; Liu, W.-Y.; Gu, W.-Y.; Li, K.-H.; Nat. Prod. Res. 2019, 33, 2662.

34. Robyt, J. F.; Essentials of Carbohydrate Chemistry, $1^{\text {st }}$ ed.; Springer: New York, 1998.

35. Park, K. J.; Cha, J. M.; Subedi, L.; Kim, S. Y.; Lee, K. R.; Phytochemistry 2019, 167, 112085.

36. Maltese, F.; Erkelens, C.; Van der Kooy, F.; Choi, Y. H.; Verpoorte, R.; Food Chem. 2009, 116, 575.

37. Gaffield, W.; Tetrahedron 1970, 26, 4093.

38. Tyukavkina, M. A.; Dem'yanovich, V. M.; Kolesnik, Y. A.; Ruchkin, V. E.; Rulenko, I. A.; Litvinenko, V. I.; Chem. Nat. Compd. 1989, 25, 157.

39. McLaughlin, J. L.; Rogers, L. L.; Drug Inf. J. 1988, 32, 513.

40. Meyer, B. N.; Ferrigni, N. R.; Putnam, J. E.; Jacobsen, L. B.; Nichols, D. E.; McLauglin, J. L.; Planta Med. 1982, 45, 31.

Submitted: November 11, 2019

Published online: April 6, 2020 